\title{
KADAR HBA1C PADA PASIEN DIABETES MELITUS TIPE 2 DI PUSKESMAS BAHU KECAMATAN MALALAYANG KOTA MANADO
}

\author{
${ }^{1}$ Mohammad R. S. Utomo \\ ${ }^{2}$ Herlina Wungouw \\ ${ }^{2}$ Sylvia Marunduh
${ }^{1}$ Kandidat Skripsi Fakultas Kedokteran Universitas Sam Ratulangi Manado
${ }^{2}$ Bagian Fisiologi Kedokteran Universitas Sam Ratulangi Manado
Email: m.utomo11_001@yahoo.com

\begin{abstract}
Diabetes mellitus (DM) is a chronic disease characterized by blood glucose levels that exceed normal values. Riskesdas in 2013 showed that North Sulawesi is one of the provinces with the highest prevalence of diabetes in Indonesia. HbA1c measurement is the most accurate way to determine blood sugar levels over the past two to three months. HbA1c is also the best single examination to assess risks to the tissue damage caused by high blood sugar levels. This study aims to determine the levels of HbA1c in patients with type 2 diabetes mellitus in Bahu Community Health Center Manado. This study is a descriptive cross sectional study. Primary data were collected through interviews, physical examination and laboratory tests. Respondents were all patients with type 2 diabetes mellitus who came in Bahu Community Health Center and willing to become respondents. The sample size is 22 people. The results of this study prove that more than half of the respondents have not controlled HbA1c levels (> 7\%) of 17 respondents. Of the 17 respondents were 9 respondents have overweight body mass index, 13 respondents not take the medicine as directed by doctor and 9 respondents did not exercise regularly. It can be concluded that the blood glucose levels of patients in Bahu Community Health Center is still not controlled, by HbA1c values above $7 \%$.
\end{abstract}

Keywords: HbA1c, Diabetes Mellitus Type 2

\begin{abstract}
Abstrak: Diabetes mellitus (DM) merupakan penyakit menahun yang ditandai oleh kadar glukosa darah yang melebihi nilai normal. Laporan Riskesdas tahun 2013 menunjukkan bahwa Sulawesi Utara merupakan salah satu provinsi dengan angka prevalensi DM yang tertinggi di Indonesia. Pengukuran HbA1c adalah cara yang paling akurat untuk menentukan tingginya kadar gula darah selama dua sampai tiga bulan terakhir. HbA1c juga merupakan pemeriksaan tunggal terbaik untuk menilai risiko terhadap kerusakan jaringan yang disebabkan oleh tingginya kadar gula darah. Penelitian ini bertujuan untuk mengetahui kadar HbA1c pada pasien diabetes melitus tipe 2 di Puskesmas Bahu Kota Manado. Penelitian ini bersifat deskriptif dengan rancangan cross sectional study. Data primer dikumpulkan melalui wawancara, pemeriksaan fisik dan pemeriksaan laboratorium. Responden adalah semua pasien diabetes melitus tipe 2 yang datang di Puskesmas Bahu dan bersedia menjadi responden. Besar sampel penelitian adalah 22 orang. Hasil penelitian ini membuktikan bahwa lebih dari setengah jumlah responden memiliki kadar HbA1c tidak terkontrol (> 7\%) sebanyak 17 responden. Dari 17 responden tersebut 9 responden memiliki indeks massa tubuh overweight, 13 responden tidak mengkonsumsi obat sesuai anjuran dokter dan 9 responden tidak rutin berolahraga. Dapat disimpulkan bahwa kadar gula darah pasien di Puskesmas Bahu masih belum terkontrol berdasarkan nilai HbA1c di atas 7\%.
\end{abstract}

Kata kunci: HbA1c, Diabetes Melitus tipe 2 
Dalam waktu 69 tahun merdeka, pola penyakit di Indonesia mengalami pergeseran yang cukup meyakinkan. Penyakit menahun yang disebabkan oleh penyakit degeneratif, di antaranya Diabetes Melitus (DM) meningkat dengan tajam. Perubahan pola penyakit ini diduga ada hubungannya dengan cara hidup yang berubah. ${ }^{1}$

Pola makan di kota-kota telah bergeser dari pola makan yang mengandung karbohidrat dan serat dari sayuran, ke pola makan dengan komposisi makanan yang terlalu banyak mengandung protein, lemak, gula, garam dan mengandung sedikit serat. Cara hidup yang terlalu sibuk dengan pekerjaan dari pagi sampai sore kadangkadang sampai malam hari duduk di belakang meja menyebabkan tidak adanya kesempatan untuk berekreasi atau berolahraga. Pola hidup "beresiko" seperti inilah yang menyebabkan tingginya angka penyakit jantung koroner (PJK), hipertensi, diabetes, dan hiperlipidemia. ${ }^{1}$

Laporan hasil Riset Kesehatan Dasar (Riskesdas) tahun 2013 oleh Departemen Kesehatan, menunjukkan bahwa prevalensi DM di Indonesia untuk usia di atas 15 tahun sebesar 6,9\%. Prevalensi DM terdiagnosis di Indonesia sebesar 2,1\%. Prevalensi diabetes yang terdiagnosis dokter tertinggi terdapat di DI Yogyakarta (2,6\%), DKI Jakarta (2,5\%), Sulawesi Utara (2,4\%), dan Kalimantan Timur (2,3\%). Hal ini menunjukkan bahwa Sulawesi Utara merupakan salah satu provinsi dengan angka prevalensi DM yang tertinggi di Indonesia. $^{2}$

Prevalensi Diabetes di Sulawesi Utara berdasarkan profil kesehatan provinsi Sulawesi Utara tahun 2008 di dapatkan angka lebih tinggi di tingkat provinsi Sulawesi Utara (1,6\%) dari pada angka nasional $(1,0 \%)$. Penyakit ini tersebar di seluruh kabupaten dan kota di Sulawesi Utara, dengan prevalensi tertinggi di kota Manado. ${ }^{3}$

Komplikasi pada DM dapat mengenai berbagai organ. Bukti-bukti menunjukkan bahwa komplikasi diabetes dapat dicegah dengan kontrol glikemik yang optimal.
Kontrol glikemik yang optimal yaitu terkendalinya konsentrasi glukosa dalam darah, HbA1c (hemoglobin terglikosilasi), kolesterol, trigliserida, status gizi, dan tekanan darah. ${ }^{4}$ Kontrol glikemik yang optimal sangatlah penting, namun di Indonesia target pencapaian kontrol glikemik belum tercapai. Rerata HbA1c masih 8\%, masih di atas target yang diinginkan yaitu 7\%. Diperlukan pencegahan dan pengelolaan yang dapat menjadi acuan penatalaksanaan diabetes melitus. Terdapat empat pilar penatalaksanaan DM yaitu edukasi, terapi gizi medis, latihan jasmani, dan intervensi farmakologis. ${ }^{1}$

Pengobatan diabetes bisa dikatakan berhasil jika glukosa darah puasa 80 sampai 109 mg/dl, kadar glukosa darah dua jam 80 sampai $144 \mathrm{mg} / \mathrm{dl}$, dan kadar HbA1c < 7\%. Pengukuran HbA1c adalah cara yang paling akurat untuk menentukan tingginya kadar gula darah selama 2-3 bulan terakhir. HbA1c juga merupakan pemeriksaan tunggal terbaik untuk menilai resiko terhadap kerusakan jaringan yang disebabkan oleh tingginya kadar gula darah. $^{5}$

Hasil tinjauan secara sistematik dan metaanalisis penelitian klinis mengenai efek intervensi latihan fisik yang terstruktur selama $\geq 8$ minggu pada kadar glukosa darah rata-rata dalam 2-3 bulan (HbA1c) dan masa tubuh pada penderita DM tipe-2, menunjukkan terjadinya penurunan HbA1c yang signifikan setelah intervensi latihan fisik dibanding kelompok kontrol (7.65 vs. 8.31\%, dengan mempertimbangkan perbedaan mean $0.66 \%$; $P<0.001) .{ }^{6}$ Suatu penelitian kasus kontrol menunjukkan bahwa olahraga teratur memiliki efek yang baik pada kadar HbA1c, kekuatan otot dan marker inflamasi pada lansia dengan diabetes. $^{7}$

Tujuan penelitian ini adalah untuk mengetahui gambaran kadar HbA1c pada penderita Diabetes Melitus Tipe 2 di Puskesmas Bahu Kecamatan Malalayang Kota Manado. 


\section{METODE PENELITIAN}

Penelitian observasional lapangan dengan rancangan cross sectional study. Subjek merupakan pasien DM Tipe 2 di Puskesmas Bahu Kota Manado dengan kriteria inklusi Diabetes Melitus Tipe 2 bulan Desember 2014 sampai bulan Januari 2015, bersedia menjadi responden dan menandatangani informed consent. Penelitian dilakukan selama bulan Oktober 2014 sampai Januari 2015. Data yang telah didapatkan, kemudian dikumpulkan dan diolah untuk mendapatkan kadar HbA1c pada pasien Diabetes Melitus Tipe 2 di Puskesmas Bahu Kecamatan Malalayang Kota Manado. Data diolah secara manual dan komputerisasi serta disajikan dalam bentuk tabel distribusi frekuensi.

\section{HASIL PENELITIAN}

Penelitian ini dilaksanakan pada bulan Oktober 2014 sampai bulan Januari 2015. Lokasi bertempat di Puskesmas Bahu Kota Manado. Responden penelitian ini adalah pasien diabetes melitus tipe 2 yang telah memenuhi kriteria inklusi dan bersedia untuk diteliti yang berjumlah 22 orang.

\section{Distribusi Karakteristik Responden Penelitian Berdasarkan Jenis Kelamin}

Tabel 1 menunjukkan sebagian besar responden dalam penelitian berjenis kelamin laki-laki yakni sebanyak 12 responden (54,5\%). Responden dengan jenis kelamin perempuan hanya berjumlah 10 responden (45,5\%).

Tabel 1. Distribusi karakteristik responden penelitian berdasarkan jenis kelamin

\begin{tabular}{ccc}
\hline Jenis Kelamin & $\mathrm{n}$ & $\%$ \\
\hline Laki-laki & 12 & 54,5 \\
Perempuan & 10 & 45,5 \\
Jumlah & 22 & 100,0 \\
\hline
\end{tabular}

\section{Distribusi Karakteristik Responden Penelitian Berdasarkan Umur}

Tabel 2 menunjukkan bahwa kelompok terbesar responden terdapat pada umur dewasa tengah yaitu antara umur 41 - 60 tahun sebanyak 16 responden (72,7\%), umur dewasa akhir yaitu di atas 60 tahun sebanyak 4 responden (18,3\%) dan paling sedikit umur dewasa awal yaitu antara 18 40 tahun sebanyak 2 responden (9\%).

Tabel 2. Distribusi karakteristik responden penelitian berdasarkan umur

\begin{tabular}{cccc}
\hline Umur (tahun) & $\mathrm{n}$ & Rerata & $\%$ \\
\hline Dewasa Awal $(18-40)$ & 2 & 33 & 9 \\
Dewasa Tengah $(41-60)$ & 16 & 52 & 72,7 \\
Dewasa Akhir $(>60)$ & 4 & 71 & 18,3 \\
Jumlah & 22 & & 100,0 \\
\hline
\end{tabular}

\section{Distribusi Karakteristik Responden Penelitian Berdasarkan Indeks Massa Tubuh}

Tabel 3 menunjukkan bahwa kelompok terbanyak responden memiliki indeks massa tubuh normal yakni sebanyak 10 responden (45,5\%), indeks massa tubuh overweight yakni 9 responden (41\%), indeks massa tubuh obesitas grade 1 yakni 2 responden (9\%), dan paling sedikit kelompok dengan indeks massa tubuh underweight yakni 1 responden $(4,5 \%)$.

Tabel 3. Distribusi karakteristik responden penelitian berdasarkan indeks massa tubuh

\begin{tabular}{cccc}
\hline $\begin{array}{c}\text { Indeks Massa Tubuh } \\
\left(\mathrm{kg} / \mathrm{m}^{2}\right)\end{array}$ & $\mathrm{n}$ & Rerata & $\%$ \\
\hline Underweight $(<18,5)$ & 1 & 17,3 & 4,5 \\
Normal $(18,5-24,9)$ & 10 & 21,5 & 45,5 \\
Overweight $(25-30)$ & 9 & 26,6 & 41 \\
Obesitas Grade 1 & 2 & 31,9 & 9 \\
$(30-34,9)$ & & & 100 \\
Jumlah & 22 & & \\
\hline
\end{tabular}

\section{Distribusi Karakteristik Responden Penelitian Berdasarkan Lama Mengidap Diabetes Melitus}

Tabel 4 menunjukkan bahwa responden terbanyak telah mengidap DM selama 1-5 tahun yakni berjumlah 12 responden (54,5 $\%)$ dan masing-masing 5 responden (22,7\%) telah mengidap DM selama kurang dari 1 
tahun dan lebih dari 5 tahun.

Tabel 4. Distribusi karakteristik responden penelitian berdasarkan lama mengidap DM

\begin{tabular}{ccc}
\hline Lama Mengidap DM & $\mathrm{n}$ & $\%$ \\
\hline$<1$ tahun & 5 & 22,7 \\
$1-5$ tahun & 12 & 54.5 \\
$>5$ tahun & 5 & 22.7 \\
Jumlah & 22 & 100,0 \\
\hline
\end{tabular}

Distribusi Karakteristik Responden Penelitian Berdasarkan Riwayat Diabetes Melitus Dalam Keluarga

Tabel 5 menunjukkan bahwa kelompok terbanyak responden memiliki riwayat DM dalam keluarga yakni sebanyak 13 responden $(59,1 \%)$ dan 9 responden tidak memiliki riwayat DM dalam keluarga.

Tabel 5. Distribusi karakteristik responden penelitian berdasarkan riwayat DM dalam keluarga

\begin{tabular}{ccc}
\hline $\begin{array}{c}\text { Riwayat DM dalam } \\
\text { Keluarga }\end{array}$ & $\mathrm{n}$ & $\%$ \\
\hline Ya & 13 & 59,1 \\
Tidak & 9 & 40,9 \\
Jumlah & 22 & 100,0 \\
\hline
\end{tabular}

\section{Distribusi Karakteristik Responden Penelitian Berdasarkan Kadar HbA1c}

Tabel 6. Distribusi karakteristik responden penelitian berdasarkan kadar HbA1c

\begin{tabular}{cccc}
\hline HbA1c(\%) & n & Rerata & $\%$ \\
\hline Normal < 6 & 4 & 5,8 & 18,2 \\
Terkontrol 6 - 7 & 1 & 6,9 & 4,5 \\
Tidak terkontrol > 7 & 17 & 9,4 & 77,3 \\
Jumlah & 22 & & 100,0 \\
\hline
\end{tabular}

Tabel 6 menunjukkan bahwa kelompok terbanyak responden memiliki kadar HbA1c tidak terkontrol yakni sebanyak 17 responden (77,3\%), diikuti responden dengan kadar HbA1c normal yakni sebanyak 4 responden (18,2\%) dan kadar
HbA1c terkontrol yakni sebanyak 1 responden $(4,5 \%)$.

\section{Distribusi Karakteristik Responden Penelitian Berdasarkan Jenis Obat yang Digunakan}

Tabel 7 menunjukkan bahwa kelompok responden terbanyak meminum obat jenis tablet yakni sebanyak 17 responden (77,3\%), dan 3 responden (13,6\%) menggunakan jenis obat suntikan serta 2 responden $(9,1 \%)$ menggunakan jenis obat tablet dan suntikan.

Tabel 7. Distribusi karakteristik responden penelitian berdasarkan jenis obat

\begin{tabular}{ccc}
\hline $\begin{array}{c}\text { Jenis Obat yang } \\
\text { digunakan }\end{array}$ & $\mathrm{n}$ & $\%$ \\
\hline Tablet & 17 & 77,3 \\
Suntikan & 3 & 13,6 \\
Keduanya & 2 & 9,1 \\
Jumlah & 22 & 100,0 \\
\hline
\end{tabular}

\section{Distribusi Karakteristik Responden} Penelitian Berdasarkan Konsumsi Obat

Tabel 8 menunjukkan sebagian besar responden dalam penelitian mengkonsumsi obat mengikuti anjuran dokter yakni sebanyak 18 responden (81,8\%) dan responden yang tidak teratur mengkonsumsi obat berjumlah 4 responden (18,2\%).

Tabel 8. Distribusi karakteristik responden penelitian berdasarkan konsumsi obat

\begin{tabular}{ccc}
\hline $\begin{array}{c}\text { Konsumsi Obat Sesuai } \\
\text { Anjuran Dokter }\end{array}$ & $\mathrm{n}$ & $\%$ \\
\hline Ya & 18 & 81,8 \\
Tidak & 4 & 18,2 \\
Jumlah & 22 & 100,0 \\
\hline
\end{tabular}

\section{Distribusi Karakteristik Responden Penelitian Berdasarkan Kerutinan Berolahraga}

Tabel 9 menunjukkan sebagian besar responden dalam penelitian tidak rutin 
berolahraga yakni sebanyak 15 responden $(63,6 \%)$ dan responden yang rajin berolahraga berjumlah 7 responden $(36,4$ $\%)$.

Tabel 9. Distribusi karakteristik responden penelitian berdasarkan rutin berolahraga

\begin{tabular}{ccc}
\hline Rutin Berolahraga & $\mathrm{n}$ & $\%$ \\
\hline Ya & 7 & 31,8 \\
Tidak & 15 & 68,2 \\
Jumlah & 22 & 100,0 \\
\hline
\end{tabular}

\section{Distribusi \\ Penelitian \\ Karakteristik \\ Berdasarkan \\ Responden \\ Olahraga}

Tabel 10 menunjukkan kelompok responden yang tidak pernah berolahraga yakni berjumlah 9 responden (40,9 \%) dan responden dengan frekuensi olahraga yang jarang yakni berjumlah 6 orang (27,3\%).

Tabel 10. Distribusi karakteristik responden penelitian berdasarkan frekuensi olahraga
Tabel 11. Distribusi responden menurut jenis kelamin dan kadar HbA1c

\begin{tabular}{|c|c|c|c|c|c|c|c|c|}
\hline & & \multicolumn{6}{|c|}{ HbA1c } & \multirow{3}{*}{ Total } \\
\hline & & \multicolumn{2}{|c|}{$\begin{array}{c}\text { Normal }< \\
6\end{array}$} & \multicolumn{2}{|c|}{$\begin{array}{c}\text { Terkontrol } \\
6-7\end{array}$} & \multicolumn{2}{|c|}{$\begin{array}{c}\text { Tidak } \\
\text { Terkontrol } \\
>7 \\
\end{array}$} & \\
\hline & & $\mathrm{n}$ & Rerata & $\mathrm{n}$ & Rerata & $\mathrm{n}$ & Rerata & \\
\hline \multirow{2}{*}{$\begin{array}{c}\text { Jenis } \\
\text { Kelamin }\end{array}$} & Laki-laki & 1 & 5,9 & 1 & 6,9 & 10 & 9,6 & 12 \\
\hline & Perempuan & 3 & 5,8 & 0 & & 7 & 9,2 & 10 \\
\hline \multicolumn{2}{|c|}{ Total } & 4 & 5,8 & 1 & 6,9 & 17 & 9,4 & 22 \\
\hline
\end{tabular}

\section{Distribusi Umur Responden Berdasarkan} Kadar HbA1c

Tabel 12. Distribusi responden menurut umur dan kadar HbA1c

\begin{tabular}{|c|c|c|c|c|c|c|c|}
\hline & \multicolumn{6}{|c|}{ HbA1c (\%) } & \multirow{3}{*}{ Total } \\
\hline & \multicolumn{2}{|c|}{$\begin{array}{c}\text { Normal } \\
<6\end{array}$} & \multicolumn{2}{|c|}{$\begin{array}{c}\text { Terkontrol } \\
6-7\end{array}$} & \multicolumn{2}{|c|}{$\begin{array}{c}\text { Tidak } \\
\text { Terkontrol } \\
>7\end{array}$} & \\
\hline & $\mathrm{N}$ & Rerata & $\mathrm{n}$ & Rerata & $\mathrm{n}$ & Rerata & \\
\hline $18-40$ & 0 & & 0 & & 2 & 8,9 & 2 \\
\hline \multirow{2}{*}{$\begin{array}{l}\text { Respoden } \\
\text { (tahun) }\end{array}$} & 3 & 5,8 & 1 & 6,9 & 12 & 9,5 & 16 \\
\hline & 1 & 5,9 & 0 & & 3 & 9,4 & 4 \\
\hline Total & 4 & 5,8 & 1 & 6,9 & 17 & 9,3 & 22 \\
\hline
\end{tabular}

\begin{tabular}{ccc} 
Frekuensi Olahraga & $\mathrm{n}$ & $\%$ \\
\hline Sering (3x seminggu) & 7 & 31,8 \\
Jarang (1x sebulan) & 6 & 27,3 \\
Tidak pernah & 9 & 40,9 \\
Jumlah & 22 & 100,0 \\
\hline
\end{tabular}

\section{Distribusi Jenis Kelamin Responden Berdasarkan Kadar HbA1c}

Tabel 11 menunjukkan 10 dari 12 responden laki-laki memiliki kadar rerata HbA1c yang tidak terkontrol yakni 9,6 \% dan 7 dari 10 responden perempuan memiliki kadar HbA1c yang tidak terkontrol yakni 9,2\%.

Tabel 12 menunjukkan 12 dari 16 responden yang berumur antara 41-60 tahun memiliki kadar HbA1c yang tidak terkontrol sebesar 9,5\% dan 3 dari 4 responden yang berumur lebih dari 60 tahun memiliki kadar HbA1c yang tidak terkontrol sebesar 9,4\%.

\section{Distribusi Indeks Massa Tubuh Responden Berdasarkan Kadar HbA1c}

Tabel 13 menunjukkan 8 dari 10 responden dengan indeks massa tubuh normal memiliki kadar HbA1c yang tidak terkontrol sebesar $10,1 \%$ dan 6 dari 9 responden dengan indeks massa tubuh overweight memiliki kadar HbA1c yang tidak terkontrol sebesar 8,8 \%. 
Tabel 13. Distribusi responden menurut indeks massa tubuh dan kadar HbA1c

\begin{tabular}{|c|c|c|c|c|c|c|c|c|}
\hline & \multicolumn{6}{|c|}{ HbA1c } & \multirow{3}{*}{ Total } \\
\hline & & \multicolumn{2}{|c|}{$\begin{array}{l}\text { Normal } \\
<6\end{array}$} & \multicolumn{2}{|c|}{$\begin{array}{c}\text { Terkontrol } \\
6-7\end{array}$} & \multicolumn{2}{|c|}{$\begin{array}{c}\text { Tidak } \\
\text { Terkontrol } \\
>7\end{array}$} & \\
\hline & & $\mathrm{n}$ & Rerata & $\mathrm{N}$ & Rerata & $\mathrm{n}$ & Rerata & \\
\hline \multirow{4}{*}{$\begin{array}{l}\text { Indeks } \\
\text { Massa } \\
\text { Tubuh }\end{array}$} & Underweight & 0 & & 0 & & 1 & 10,1 & 1 \\
\hline & Normal & 2 & 5,9 & 0 & & 8 & 10,1 & 10 \\
\hline & Overweight & 2 & 5,7 & 1 & 6,9 & 6 & 8,8 & 9 \\
\hline & Obese 1 & 0 & & 0 & & 2 & 7,8 & 2 \\
\hline & Total & 4 & 5,8 & 1 & 6,9 & 17 & 9,2 & 22 \\
\hline
\end{tabular}

Distribusi Riwayat DM Dalam Keluarga Responden Berdasarkan Kadar HbA1c

Tabel 14 menunjukkan bahwa 11 dari 13 responden yang memiliki riwayat DM dalam keluarga memili rerata kadar HbA1c $8,8 \%$.

Tabel 14. Distribusi responden menurut riwayat DM dalam keluarga dan kadar HbA1c

\begin{tabular}{|c|c|c|c|c|c|c|c|c|}
\hline & \multicolumn{6}{|c|}{ HbA1c } & \multirow{3}{*}{ Total } \\
\hline & & \multirow{2}{*}{\multicolumn{2}{|c|}{$\begin{array}{l}\text { Normal } \\
<6\end{array}$}} & \multicolumn{2}{|c|}{$\begin{array}{c}\text { Terkontrol } \\
6-7\end{array}$} & \multicolumn{2}{|c|}{$\begin{array}{c}\text { Tidak } \\
\text { Terkontrol } \\
>7\end{array}$} & \\
\hline & & & & $\mathrm{n}$ & Rerata & $\mathrm{n}$ & $\begin{array}{c}\text { Rera } \\
\text { ta }\end{array}$ & \\
\hline $\begin{array}{c}\text { Riwayat } \\
\text { DM }\end{array}$ & Ya & 1 & 5.9 & 1 & 6.9 & 11 & 8.8 & 13 \\
\hline $\begin{array}{c}\text { Dalam } \\
\text { Keluarga }\end{array}$ & Tidak & 3 & 5.8 & 0 & & 6 & $\begin{array}{c}10 . \\
4\end{array}$ & 9 \\
\hline Tot & & 4 & 5.8 & 1 & 6.9 & 17 & 9.6 & 22 \\
\hline
\end{tabular}

\section{Distribusi Jenis Obat Responden Berdasarkan Kadar HbA1c}

Tabel 15. Distribusi responden menurut jenis obat dan kadar HbA1c

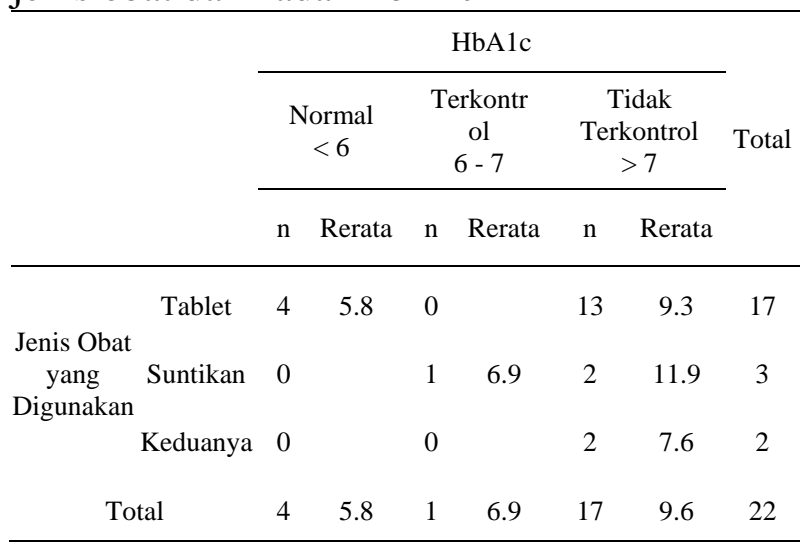

Tabel 15 menunjukkan bahwa 13 dari 17 responden yang menggunakan obat jenis tablet memiliki rerata kadar HbA1c tidak terkontrol yakni 9,3 \% dan 2 dari 3 responden yang menggunakan obat jenis suntikan memiliki rerata kadar HbA1c tidak terkontrol yakni 11,9\%.

\section{Distribusi Konsumsi Obat Responden Berdasarkan Kadar HbA1c}

Tabel 16 menunjukkan 13 dari 18 responden yang mengkonsumsi obat sesuai anjuran dokter memiliki kadar HbA1c yang tidak terkontrol sebesar 9,1 \% dan semua responden yang tidak mengkonsumsi obat sesuai anjuran dokter memiliki kadar HbA1c yang tidak terkontrol sebesar 10,4 $\%$.

Tabel 16. Distribusi responden menurut konsumsi obat dan kadar HbA1c

\begin{tabular}{ccccccccc}
\hline & & \multicolumn{6}{c}{ HbA1c } & \\
\cline { 3 - 7 } & & $\begin{array}{c}\text { Normal } \\
<6\end{array}$ & $\begin{array}{c}\text { Terkontrol } \\
6-7\end{array}$ & $\begin{array}{c}\text { Tidak } \\
\text { Terkontrol } \\
>7\end{array}$ & Total \\
\cline { 3 - 7 } & & $\mathrm{n}$ & Rerata & $\mathrm{n}$ & Rerata & $\mathrm{n}$ & Rerata & \\
\hline $\begin{array}{c}\text { Konsumsi } \\
\text { Obat }\end{array}$ & Ya & 4 & 5,8 & 1 & 6,9 & 13 & 9,1 & 18 \\
\multicolumn{1}{c}{ Total } & & 4 & 5,8 & 1 & 6,9 & 17 & 9,7 & 22 \\
\hline
\end{tabular}

\section{Distribusi Kerutinan Berolahraga Responden Berdasarkan Kadar HbA1c}

Tabel 17. Distribusi responden menurut kerutinan berolahraga dan kadar HbA1c

\begin{tabular}{|c|c|c|c|c|c|c|c|}
\hline & \multicolumn{6}{|c|}{ HbA1c } & \multirow{3}{*}{ Total } \\
\hline & \multicolumn{2}{|c|}{$\begin{array}{l}\text { Normal } \\
<6\end{array}$} & \multicolumn{2}{|c|}{$\begin{array}{c}\text { Terkontrol } \\
6-7\end{array}$} & \multicolumn{2}{|c|}{$\begin{array}{c}\text { Tidak } \\
\text { Terkontrol } \\
>7 \\
\end{array}$} & \\
\hline & $\mathrm{n}$ & Rerata & $\mathrm{n}$ & Rerata & $\mathrm{n}$ & Rerata & \\
\hline Rutin & 0 & & 0 & & 7 & 9,2 & 8 \\
\hline Olahraga Tidak & 4 & 5,8 & 1 & 6,9 & 10 & 9,5 & 14 \\
\hline Total & 4 & 5,8 & 1 & 6,9 & 17 & 9,4 & 22 \\
\hline
\end{tabular}

Tabel 17 menunjukkan 8 responden yang berolahraga rutin memiliki kadar HbA1c yang tidak terkontrol sebesar 9,2 \% dan 9 dari 14 responden yang tidak berolahraga rutin memiliki kadar HbA1c yang tidak terkontrol sebesar 9,5 \%. 


\section{Distribusi Frekuensi Olahraga Responden Berdasarkan Kadar HbA1c}

Tabel 18 menunjukkan bahwa 6 dari 9 responden yang tidak pernah berolahraga memiliki rerata kadar HbA1c tidak terkontrol yakni 9,8 \%.

Tabel 18. Distribusi responden menurut frekuensi olahraga dan kadar HbA1c

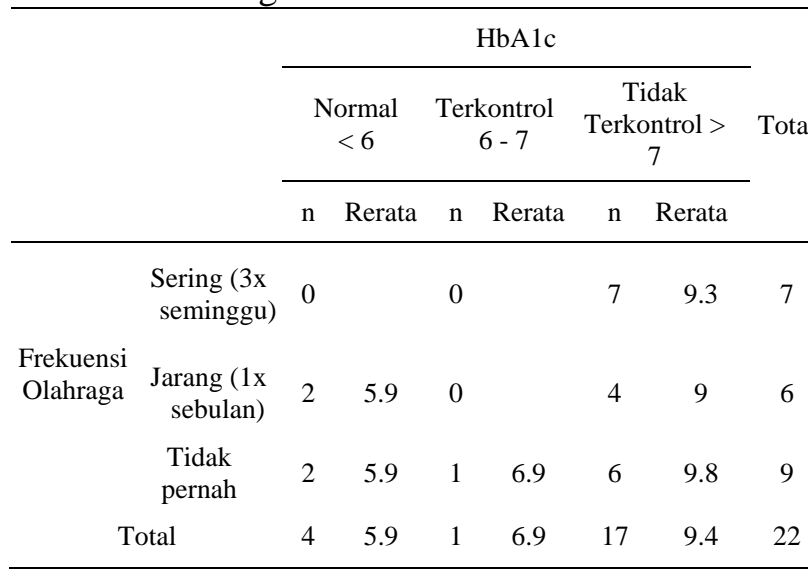

\section{BAHASAN}

Hasil penelitian dari 22 responden pasien DM tipe 2 didapatkan 17 responden (77,3\%) memiliki kadar HbA1c yang tidak terkontrol yaitu di atas 7\%. Kadar HbA1c yang tidak terkontrol dapat menyebabkan komplikasi oleh karenanya bagi para penyandang diabetes, ADA (American Diabetes Association) merekomendasikan bahwa kadar HbA1c dinyatakan terkontrol apabila berada $<7 \%$ dan tidak terkontrol jika $>7 \%{ }^{8}$

Hasil dari penelitian ini menunjukkan bahwa rerata kadar HbA1c pada responden dengan indeks massa tubuh normal $(18,5-$ $24,9 \mathrm{~kg} / \mathrm{m}^{2}$ ) yaitu sebesar $10,1 \%$, lebih tinggi daripada rerata kadar HbA1c pada responden dengan indeks massa tubuh overweight $\left(25-30 \mathrm{~kg} / \mathrm{m}^{2}\right)$ yaitu sebesar $8,8 \%$. Hasil penelitian ini tidak sejalan dengan hasil penelitian yang diperoleh peneliti lain. Seperti hasil penelitian Achmad Yoga yang menunjukkan bahwa pasien dengan indeks massa tubuh yang normal seharusnya mempunyai kadar HbA1c yang terkontrol. ${ }^{9}$ Namun hasil penelitian ini relevan dengan hasil penelitian Asticaliana yang menyimpulkan bahwa tidak terdapat hubungan bermakna antara kadar HbA1c dengan indeks massa tubuh berlebih. ${ }^{10}$ DM tipe 2 sangat erat kaitannya dengan obesitas. Pada penderita DM tipe 2, pancreas tetap menghasilkan insulin dalam jumlah yang cukup untuk mempertahankan kadar glukosa darah pada tingkat normal, namun insulin tersebut tidak dapat bekerja maksimal untuk membawa glukosa ke dalam sel karena tingginya kadar kolesterol dan trigliserida pada orang yang mengalami obesitas. ${ }^{11}$

Pada penelitian ini 13 dari 22 responden yang mengkonsumsi obat sesuai anjuran dokter di dapatkan rerata kadar HbA1c sebesar 9,1\%, yang mana lebih rendah daripada rerata kadar HbA1c 6 responden yang tidak mengkonsumsi obat sesuai anjuran dokter yaitu sebesar 10,4\%. Tetapi, walaupun rerata kadar HbA1c responden yang mengkonsumsi obat sesuai dengan anjuran dokter lebih rendah, hasil rerata kadar HbA1c keduanya tergolong tidak terkontrol (> 7\%). Hasil penelitian ini tidak sesuai dengan penelitian Pranoto tahun 2012 di 10 puskesmas wilayah Surabaya menemukan 99 pasien yang memakai OHO (Obat Hipoglikemik Oral) selama 6 tahun tidak dapat mengendalikan kadar glukosa darah ditandai dengan kadar HbA1c mencapai 11\%. Namun, sejalan dengan hasil penelitian Achmad Yoga dimana didapatkan odds rasio (OR) sebesar 4,03 dengan nilai $\mathrm{P}=0,01<(0,05)$ menunjukkan bahwa orang yang mempunyai kepatuhan minum obat memiliki kesempatan 4 kali lebih baik untuk berhasil dalam pengelolaan DM tipe 2 dibandingkan dengan yang tidak patuh minum obat dan secara statistik bermakna. ${ }^{9}$

Berdasarkan hasil penelitian ini didapatkan 8 dari 22 responden yang berolahraga secara rutin memiliki rerata kadar HbA1c sebesar 9,2\% dimana lebih rendah daripada rerata kadar HbA1c responden yang tidak rutin berolahraga sebesar 9,5\%. Hasil ini sesuai dengan hasil penelitian sebelumnya, seperti yang dikemukakan oleh Ramadhanisa yang menyatakan bahwa ada hubungan yang bermakna antara aktivitas fisik dengan kadar HbA1c pada pasien DM tipe $2 .^{12}$ 
Kurangnya aktivitas fisik menyebabkan kurangnya pembakaran energi oleh tubuh sehingga kelebihan energi dalam tubuh akan disimpan dalam bentuk lemak dalam tubuh. ${ }^{3}$ Penelitian ini dalam pelaksanaannya ditemui berbagai keterbatasan. Keterbatasan yang dihadapi antara lain kurangnya responden yang disebabkan oleh singkatnya waktu penelitian dan keterbatasan wilayah yang hanya mencakup 1 puskesmas saja.

\section{SIMPULAN}

Dari hasil penelitian dapat disimpulkan bahwa kadar HbA1c pada sebagian besar responden yaitu 17 responden (77,3\%) di Puskesmas Bahu menunjukkan kadar tidak terkontrol yang terdiri dari 6 responden memiliki indeks massa tubuh overweight, 13 responden tidak mengkonsumsi obat sesuai anjuran dokter dan 10 responden tidak rajin berolahraga.

\section{SARAN}

Disarankan bagi responden yang memiliki kadar HbA1c tidak terkontrol agar memperbaiki pola hidup seperti lebih rutin berolahraga dan mengkonsumsi obat sesuai anjuran dokter serta memeriksakan kadar HbA1c secara rutin setiap tiga bulan sekali untuk mengecek keberhasilan pengobatan, penelitian lanjut diperlukan jumlah responden yang lebih dari penelitian ini dan wilayah cakupan yang lebih luas, serta penelitian ulang ataupun pemeriksaan lanjut pada responden yang masih tidak terkontrol kadar HbA1c.

\section{UCAPAN TERIMA KASIH}

Ucapan terima kasih disampaikan kepada semua pihak yang baik secara langsung maupun tidak langsung telah menumbuhkan ide/gagasan dalam pemikiran penulis sehingga dapat menyelesaikan artikel ini.

\section{DAFTAR PUSTAKA}

1. Purnamasari D. Diagnosis dan klasifikasi diabetes melitus. Sudoyo AW, Setiyohadi B, Alwi Idrus, Simadibrata M, Setiati S. Dalam: Buku ajar ilmu penyakit dalam jilid III. Edisi V.
Jakarta: Internal Publishing; 2009. h. 1880.

2. Hasil Riset Kesehatan Dasar (Riskesdas). Jakarta: Badan Penelitian dan Pengembangan Kesehatan, Kementrian Kesehatan RI; 2013. www.depkes.go.id/resources/download/ general/Hasil\%20Riskesdas\%202013.pd f (Diakses pada tanggal 15 September 2014).

3. Refa S, Dewi NA. Hubungan antara HbA1c dan kadar lipid serum dengan derajat berat retinopati diabetika. Jurnal Kedokteran Brawijaya. 2005;21:141.

4. Qurratuaeni. Faktor-faktor yang berhubungan dengan terkendalinya kadar gula darah pada pasien diabetes melitus di rumah sakit umum pusat (RSUP) fatmawati Jakarta. Skripsi Fakultas Kedokteran dan Ilmu Kesehatan UIN Syarif Hidayatullah. 2009;h.52.

5. Rismayanthi C. Terapi insulin sebagai alternatif pengobatan bagi penderita diabetes. Dosen Pendidikan Kesehatan dan Rekreasi. http://staff.uny.ac.id/sites/default/files/p enelitian/Cerika\%20Rismayanthi,\%20S. Or./TERAPI\%20INSULIN\%20SEBAG AI\%20ALTERNATIF\%20PENGOBAT AN.pdf (Diakses pada tanggal 9 Oktober 2014).

6. Rachmawati Ova. Hubungan latihan jasmani terhadap kadar glukosa darah penderita diabetes melitus tipe-2. Skripsi Fakultas Kedokteran Universitas Sebelas Maret. 2010;h.2,8-9.

7. Fitriyah L, Sunarti S. Aktifitas fisik meningkatkan kekuatan otot dan mengurangi tanda-tanda inflamasi pada pasien lansia dengan diabetes. Jurnal Kedokteran Brawijaya. 2014;28:154.

8. American Diabetes Association (ADA). Standards of medical care in diabetes. Diabetes Care: 27; 2004.

9. Utomo AYS. Hubungan antara 4 pilar pengelolaan diabetes melituus dengan keberhasilan pengelolaan diabetes melitus tipe 2. Artikel Karya Tulis Ilmiah Fakultas Kedokteran Universitas Diponegoro. 2011;h.16-7.

10. Putri AES, Larasati TA. Hubungan obesitas dengan kadar HbA1c pasien diabetes melitus tipe 2 di laboratorium patologi klinik rumah sakit umum daerah abdul moeloek provinsi lampung. Medical 
Jurnal e-Biomedik (eBm), Volume 3, Nomor 1, Januari-April 2015

Journal of Lampung University. 2013;2:h.15-6.

11. Diabetes dan obesitas (kegemukan). http://olvista.com/kesehatan/diabetesdan-obesitas-kegemukan/

((Diakses pada tanggal 20 Januari 2015)
12. Ramadhanisa A, Larasati TA, Mayasari D. Hubungan aktivitas fisik dengan kadar HbA1c pasien diabetes melitus tipe 2 di laboratorium patologi klinik RSUD dr. H. abdul moeloek Bandar lampung. Medical Journal of Lampung University. 2013;2:h.49-50. 